\title{
The Present Situation and Re-protection of Intangible Cultural Heritage NiNigou
}

\author{
Chunxin Ruan ${ }^{1}$ \\ ${ }^{1}$ Yinghe Senior High School of Zhoukou, Huayaocheng Campus, Zhoukou, China \\ Correspondence: Chunxin Ruan, Yinghe Senior High School of Zhoukou, Huayaocheng Campus, North Ring \\ Road, Chuanhui District, Zhoukou, Henan, China. E-mail: 1150812136@qq.com
}

Received: January 28, 2022

doi:10.20849/ajsss.v7i2.1011
Accepted: February 22, 2022

Online Published: February 27, 2022

URL: https://doi.org/10.20849/ajsss.v7i2.1011

\begin{abstract}
As an intangible cultural heritage, NiNigou has its body made of yellow soil and its clothes made of colorful dot painting on black background. The patterns painted on its body are not only the embodiment of artistic quality, but also contain the totem culture of thousands of years of human civilization and wisdom. Therefore, the author led the social practice team to Huaiyang, the birthplace of NiNigou. By visiting Mr. Ren Guohe, the inheritor of NiNigou culture, I had an in-depth understanding of the production process of NiNigou, the significance of cultural symbols and the contemporary value, so as to explore how to better protect and inherit the intangible cultural heritage of NiNigou.
\end{abstract}

Keywords: NiNigou, protect and promote, intangible cultural heritage

\section{The Background of the NiNigou}

The history of intangible cultural heritage is not only from the moment when the World Intangible Cultural Heritage Convention was made, but also as long as the appearance of human culture. The "true totem" of NiNigou in Huaiyang, with a history of more than 6,000 years, is one of the most typical representatives of intangible cultural inheritance. It is said that in ancient times, Huaiyang was the old capital of Fuxi, the first of the "three sovereigns and five emperors". NiNigou is a reflection of the legendary story of Fu Xi and $\mathrm{Nu} \mathrm{Wa} \mathrm{in}$ China. The thousands of NiNigou forms embody the various characters and scenes in the legend, carrying ancient worship.

"Ninhao" is a special product of Huaiyang County, Henan Province. It is a well-known clay sculpture art in the eastern Part of Henan Province. It is the general name of clay toys in Huaiyang Taihao Ling Temple Fair. It is a unique folk art produced under the primitive totem culture, and it is also a "sacred thing" for pilgrims to avoid disaster, seek happiness and scramble to buy. NiNigou, a manifestation of traditional handicraft, was identified as an intangible cultural heritage of Henan Province in 2009.

There are many different versions of the NiNigou legend and this one is probably the one that has been passed on by word of mouth the most. Legend has it that $\mathrm{Fu} \mathrm{Xi}$ and $\mathrm{Nu}$ Wa used the leftover mud to make people into chickens and dogs and sprinkled them on the earth. NiNigou is the "god dog" looking after the mausoleum temple for $\mathrm{Fu} \mathrm{Xi}$ and $\mathrm{Nu}$ Wa. In ancient times it was believed that NiNigou can "cure". It is said that the pilgrims from different parts of the world take "NiNigou" back to their hometown. Besides giving it to their children, grandchildren, relatives and friends, they also need to throw some of it into the well, saying that drinking the water from the well can "clear the mind and clear the eyes, and cure all kinds of diseases". From this, NiNigou is also called "spirit dog". Also, traveling merchants, no matter go to the ends of the earth, as long as you from the "NiNigou" body button a little soil to drink tea, you can cure acclimatization or "homesickness". No wonder the overseas friends and compatriots from Hong Kong, Macao and Taiwan who came to Huaiyang to burn incense all reverently took a towel from Tai Hao Ling to carry yellow clay back before leaving. It seems that it is also for the cure of nostalgia for the motherland. With the rapid development of society, the inheritance of culture should always be in mind. There are always some craftsmen and craftsmen who stick to the traditional culture for us.

\section{NiNigou Craft Inheritor-Mr. Ren Guohe}

Mr. Ren Guohe is one of the inheritors of NiNigou and the director of Huaiyang NiNigou Professional cooperative. He is over seventy years old this year and has been making NiNigou for sixty years. Mr. Ren Guohe 
introduced to the author the process of making NiNigou in detail, from embryo making to drying to coloring, and showed the author various semi-finished products and finished products. Then he explained in detail for us each NiNigou above special symbols to represent specific meaning. According to Mr. Ren Guohe, the most important part of NiNigou body is the meaning of represents. Reproduction is the most important part of it. The arrangement of stripes and dots on the body is not random, but has a specific meaning. The patterns above are accumulated bit by bit by the working people according to their lives. And NiNigou is not just a legacy, it is called a "living fossil" because it is still in the process of growth and innovation.

\section{Interview With Mr. Ren Guohe and Visit NiNigou Warehouse}

The author followed Mr. Ren Guohe to visit the first floor of the warehouse.

Ren Guohe: Now let me introduce them to you. This is a dry billet. After kneading the mixed mud, it is dried in the shade when it reaches $50 \%$. Why sunburn it to $50 \%$ ? Because if bask in time for a long time, it will dry and crack the skin surface will change. After this step, it will almost be molded, and then coated with black into black, becoming a unique huaiyang NiNigou in China. This black bottom is a saying and origin, black bottom after completion, to go through colorful dot painting, and then the processing of other steps, this is the manual process we handed down.

The author: Do you need to use molds for NiNigou processing?

Ren Guohe: we must use moulds. Why do we use moulds? Because in our processing and packaging, consumers require a unified standard of quality, and then there are certain standards for specifications and sizes, our manual is always a little inferior to the mold, so that it can be very good to complete this step. No matter how high my technology is, it is not as accurate as the machine. The precision of the machine is the same size and thickness, and the quality is not different. The most basic thing for NiNigou to be sold to more people is to have a uniform specification, this specification is required. Hammering mud, kneading, drying, base painting, five-color spot painting, this is NiNigou five processes. The second floor is our original second exhibition hall, we do not pay attention to environmental requirements, but to see the craftsmanship of our works.

The author followed Mr. Ren Guohe to visit the second floor of the warehouse.

Ren Guohe: This is the certificate we got, the Ministry of Agriculture, the Ministry of Culture, and the Intangible Cultural Heritage Protection Department. This is the brand of our rural co-operative, the only one in the country making NiNigou. All over the country, only the people in Huaiyang, Henan province can do NiNigou. In Huaiyang, there is only one special NiNigou village, and there is only one cooperative in this village- NiNigou Agricultural Cooperative, Jinhui, Huaiyang county, Henan Province. There are altogether ten inheritors of intangible culture in our cooperative. This is an inheritor, all of whom are taught by me. There are more than 30 families in the cooperative, 128 people in total. They are all made in their own homes and shipped here after finishing, and then we carry out follow-up processing. In this way, they can earn one or two million yuan each year.

Our cooperative was founded in 2010, it has been eight years now, but I have been making NiNigou for 64 years, and now I am 71 years old. There is not much in my house, only NiNigou is the largest. Our house is very messy at first impression, because there are so many NiNigou in it that we can't count them. This point you don't care, you casually shoot, casually watch, like to shoot more, more propaganda. I would love and love to sacrifice my time to teach you all the knowledge of NiNigou culture, as long as you don't mind my poor presentation. When I see you, I will like you very much and think of my grandchildren. They usually go to school in other places. Every year when I go home for festivals, I will do NiNigou with them. Therefore, as an old man in my family, it is only natural for me to do what I can to contribute to the young.

The author went to Visit NiNigou in Mr. Ren Guohe's house.

Ren Guohe: NiNigou is divided into reproductive worship series, group native man series, totem series, traditional mascot series, modern mascot series, Twelve Zodiac series, flower goods series. NiNigou contains the evolution of human beings, from ape to man, from matriarchy to patrilineal society, from fishing and hunting to farming age, the crystallization of the artistic wisdom of working people. Before, NiNigou was different in shape, unique in shape and rougher. Now, NiNigou is much more delicate than before. Let me start with the reproductive worship series, which we call the progenitor monkey, and this side we call the crown. The crowned web name is god, and the main aspect of this is the ape that has not evolved into an adult. But because of this crown, we can think of it as the unity of man and God, which is God. This painting is solemn and dignified, very upright, not crooked, not with that smile, this is our god, we have to respect them. Underneath it is the reproductive symbols of those people, and this one is the reproductive symbols of women, drawn in a very 
exaggerated way. There is a saying that this painting method, our ancestors at the earliest time was a matriarchal society, so painting so big is a kind of respect to it, so it is the most precious and precious cultural inheritance. These little symbols up here, we can't call them dots, and this one we call tadpole letters. There are a lot of dots on huaiyang NiNigou, the layman will call them dots, but the real expert knows that this is a symbol, this is a kind of writing. Master figures do not take special care of the standardization of symbols in their paintings, or draw exactly the same. Master figures paint the symbols as they please, just to express the symbols. So the tadpole pattern painted on the monkey ninhao, the god pattern, in the eyes of foreigners, is our Oriental holy relic.

The second series is mother and child monkey, this series of works more, there are more than 80 kinds. Let me pick a few that are common and typical. The term goes back to matrilineal societies, when children were born knowing their mother but not their father, where mother and child were the most common family matches. The reason why we want to make the protrusion of this NiNigou belly is to let others know that there is another life in the womb, showing the state of the mother and child as one.

The third series of NiNigou is the name for unicorn, which is very strong and powerful. There are two series of NiNigou unicorns in Huaiyang, one of which means to eliminate evil and ward off evil. This is not a four-legged unicorn standing on two legs. The symbol means to protect the powerful men in the tribe, to protect the safety of the tribe. This is the symbol of male reproduction, from the single maternal reproduction worship to bisexual reproduction worship, which is a great progress of civilization. It took 6,000 years of historical evolution to get to this point where it became a hermaphrodite cult, a major step forward in human civilization.

Next, we will call this series straw Hat Tiger. "Tiger" is also called "Fu" and "Fuxi", which stands for human, so the image of straw hat Tiger is standing up. Why the straw hat? Because this straw hat is used to hide shame, before people did not have those cloth silk, there is no way to cover the face, can only use straw hat to cover. In the past, Fuxi and Nuwa, as the ancestors of human beings, married for the sake of human reproduction. Because it did not conform to ethical common sense, they made straw hats to cover their shame. There is another story about a rolling stone getting married: the sky fell and the flood flooded the vast ocean everywhere. Most of the people in the world died in the disaster, leaving only Fuxi and Nuwa. They felt very lonely, for there was no one else to talk to them, and if they died, there would be no one in the world. Who would see such a beautiful world? So Fuxi proposed to marry Nuwa and reproduce the human race. But his sister disagreed, saying, "We are brother and sister. How can we get married?" Fuxi said, "If we don't get married, there will be no more human beings in the world." Nuwa a thought is also reasonable, but also want to see how the will of Heaven, so up to heaven divination. Divination showed such a scene: Fuxi and Nuwa are alone and have no support. They want to live together and hesitate because of the relationship between brother and sister. In the end they decided to consult providence to make their choice. So one took a needle and the other a thread and threw them down from the high cliff. Down the cliff, the thread was in the eye of the needle. To be prudent, they decided to make another experiment. They found a mill, one pushing it up, the other pushing it down, and rolling it down the hill at the same time. When he came down the mountain, he saw two stone mills neatly stacked together. Both things happened, so the brother and sister became husband and wife and had children, and the world developed again.

There are many other fairy tales about Fuxi and Nuwa, and they all regard Fuxi and Nuwa as the ancestor of the Chinese nation, conveying people's respect and worship to their ancestors. Nowadays, many handicraftsmen call these colors color and like which color they like. For example, there is a white dot here and a yellow dot there, but they are wrong in this way. The traditional kind of craft is to paint with colorful dots, colorful is red, yellow, black, white, green, red is the sun, white is the night. Huaiyang NiNigou no special image to show the appearance of the animal, is a certain abstraction.

Ren Guohe: These works belong to the standard five color spot painting, five colors including red, yellow, green, white and black with a background. This is the standard for NiNigou in Henan Province. There is a great variety of NiNigou works, each with its own characteristics, there is no duplication of works. There are many kinds of exorcism, safety, blessing, population prosperity, parents, pray for college......

\section{NiNigou Production Process}

Huaiyang NiNigou style antique, grotesque, gorgeous color, with black bottom, with colorful decoration around the body, about hundreds of varieties. NiNigou is divided into seven series: reproductive worship series, God made man series, totem series, traditional mascot series, modern mascot series, zodiac series and flower life series. The seven series are listed in order of importance, so let's take a look at each of them.

The first is the fertility cult series. Reproduction worship is a popular custom in primitive society. It is a kind of expression that primitive society ancients pursue happiness and hope cause flourishing. The so-called 
reproduction worship is a kind of praise and yearning for the reproduction ability of the reproduction circle. The "female reproduction worship" emblem in NiNigou is reproducing the charm of primitive totem art, giving the ancient clay sculpture art a strong visual impact and modern sense. The second is the God Made Man series. According to the Bible, God created a man and a woman and named them Adam and Eve. God blessed them to be fruitful and multiply, and gave them for food fruits and vegetables and animals. Huaiyang NiNigou also has the description of the story. The third is the totem series. Huaiyang NiNigou makes people feel like going back to the ancient times when chaos started. Human beings themselves are fragile, so they put the hope of protecting themselves on some animals with great deterrence, and regard everything as the carrier of soul, which gives rise to the "totem" worship of animal spirits. The fourth is the traditional mascot series. China's traditional mascots include the Kylin, the Phoenix, the turtle and the dragon, auspicious beasts that can ward off evil spirits and bring good luck to their owners. The image of NiNigou, a traditional mascot, symbolizes good luck.

The last three are the modern mascot series, the Twelve Zodiac series and the Little Flower series. With the trend of The Times, the NiNigou variety is also developing. Modern mascot series, is with the development of society, there are some modern mascots, such as Fuwa, Haibao and so on. The twelve zodiac series is the appearance of the rat, ox, tiger, rabbit, dragon, snake, horse, sheep, monkey, rooster, dog and pig. The little flower living series is the small, cheap, whistled, blowing NiNigou in the market. There are many kinds of NiNigou, each of which is a symbol of traditional Chinese culture.

NiNigou production material is actually very simple, the main raw material is mud, followed by the color of NiNigou pigment. The so-called one side of soil and water to nurture one side, ninyang mud is from local huaiyang, from the Longhu of Huaiyang, local material is also a characteristic of Huaiyang NiNigou.

First, you need to beat the mud, which is collected by mixing it with water and breaking it into pieces.

Then, it is to make the clay into the desired shape by hand, also known as molding. Due to the increase in demand, there are also some moulds available. You can take the lump of mud to your desired size and put it into the mould. NiNigou styling is straightforward and casual, without any strict styling, no complicated twists and details, NiNigou styling is completely from the accumulated experience of the producer for a long time.

After that, dye: Black dye should be applied to the molded NiNigou. When the molded NiNigou has been completely colored, take it out and dry it in the sun. The air drying here also has the requirement, when the air is basked in, must be put in the cool place, the requirement is dry in the shade, must not bask in directly with the sun.

Finally, color: The last step is to color the black NiNigou, using colored pigments to make it look good. NiNigou color is not colorful any color can be, mainly red, white, yellow, green, blue five colors. The coloring process is also very casual and simple, mainly composed of arc curves, points and lines, the lines are very rough and vivid.

\section{NiNigou Sales}

During our investigation, the author found that the sales of NiNigou are not optimistic. The sales scope is very small, and they are only sold locally, such as in temple fairs or in local scenic spots such as Tai Hao Ling. According to the interview of the author, in recent years, there has been a gradual decrease in the number of NiNigou businesses. More and more people think that the profit of selling NiNigou is low, so many people choose to go out to earn money. Mr Ren also said that most of the people he employs are women who stay at home to make NiNigou in his workshop in between taking care of their children.

From the reality of NiNigou, we can see that this intangible cultural heritage of NiNigou is not as optimistic as you might expect. It is obvious from the reality of NiNigou, although we cannot use the price of NiNigou to see whether there is a value of NiNigou, it is an indisputable fact that fewer and fewer people are learning to make NiNigou because making NiNigou does not make money. I hope that you can pay attention to the protection of intangible cultural heritage, so that NiNigou can be passed on.

\section{The Future Development of NiNigou}

Development requires inheritance. Traditional art has become a recognized and respected art because of its previous craftsmanship and the meaning and spirit it represents. We cannot abandon its essential meaning, need to pass down the craft handed down from the past, so that the next generation to inherit, appreciate, remember, from these vivid NiNigou feeling aura.

Development requires innovation. The Times are changing and people's value needs are changing, which is also pulling the development of NiNigou in the future. NiNigou also needs more novelty and variety in its styling, style and packaging so as to develop better. In addition, it is necessary to continue the publicity. With the help of 
the most popular short video media such as Douyin and Kuaishou, it can break the regional bondage and let more people see the cultural charm of NiNigou.

Development needs young people. Mr. Ren Guohe once said that the development of NiNigou needs the efforts of our younger generation, because most of the people who are learning the craft now are middle-aged and lack innovation and methods. He is also willing to recruit apprentices. I also hope that more people can know about NiNigou, so as to be involved in the inheritance of this craft. It is true that it is not as extensive and exquisite as embroidery, nor as well-known as papercuts, but the NiNigou culture, as a bright pearl in the extensive and profound Chinese culture, is amazing. We should also live up to the mission, remember the traditional culture in the current society, good protection of NiNigou, let the beautiful things in everyone's heart.

\section{My Feelings}

In this practice, the author visited Mr. Ren Guohe for many times and had a good conversation with him. We talked about Mr. Ren's 40 years of NiNigou production, the development status of NiNigou under the leadership of NiNigou Association, and the innovation for the future development of NiNigou. Now, under the leadership of the craftsmen led by Mr. Ren Guohe, the whole village is carrying on the NiNigou intangible heritage culture, which has a good market and a good income. Of course, there are many challenges for the development of NiNigou at present. As Mr. Ren Guohe said, young people like trendy things. The traditional NiNigou species cannot be changed, such as the hominid monkey, which is not handed down from its ancestors, but the new NiNigou species can be used by the skilled hands of the craftsmen to meet the needs of everyone. I believe that Mr. Ren Guohe's idea, combined with the current trend, such as the Winter Olympics ice Dwen Dwen, will capture the hearts of the younger generation.

Speaking of the NiNigou heritage, Mr. Ren Said, "I have been working for 40 years, and my whole life is destined to be dedicated to the igou industry. My son is also doing the igou industry. My grandson is going to follow his will; I will not force him to learn it. The NiNigou heritage did not come through my family." Think carefully, is not so? NiNigou should be passed on, not by one family, but by the masses. Huaiyang NiNigou is not personal, but everyone's. Inheritance naturally depends on everyone. Only with the strength of the masses can the tradition be passed on.

\section{References}

Li, K. (2014). Chen Chu Style: Characteristics and Form of Chen Chu Culture (Vol. 5, pp. 204-221). Beijing: Modern Press.

Ni, B.-C. (1999). Huaiyang NiNigou (Vol. 3, pp. 23-46). Harbin: Heilongiiang Fine Arts Publishing House.

Sun, L., \& Liu, Z.-H. (2017). Huaiyang NiNigou (Vol. 3, pp. 77-127). Beijing: China Light Industry Press.

Xu, J.-G. (2020). Chinese Colored Plastic Art (Vol. 8, pp. 481-485). Beijing: Tsinghua University Press.

\section{Copyrights}

Copyright for this article is retained by the author(s), with first publication rights granted to the journal.

This is an open-access article distributed under the terms and conditions of the Creative Commons Attribution license (http://creativecommons.org/licenses/by/4.0/). 